\title{
Rethinking risk and disasters in mountain areas
}

\section{Kenneth Hewitt and Manjari Mehta}

\section{(2) OpenEdition}

\section{Journals}

Electronic version

URL: https://journals.openedition.org/rga/1653

DOI: 10.4000/rga.1653

ISSN: $1760-7426$

Translation(s):

Repenser le risque et les catastrophes dans les régions de montagne - URL : https:// journals.openedition.org/rga/1650 [Fr]

Publisher:

Association pour la diffusion de la recherche alpine, UGA Éditions/Université Grenoble Alpes

Electronic reference

Kenneth Hewitt and Manjari Mehta, "Rethinking risk and disasters in mountain areas", Journal of Alpine Research / Revue de géographie alpine [Online], 100-1 | 2012, Online since 14 May 2012, connection on 08 December 2022. URL: http://journals.openedition.org/rga/1653 ; DOI: https://doi.org/10.4000/rga. 1653

This text was automatically generated on 8 December 2022.

\section{(†)

Creative Commons - Attribution-NonCommercial-NoDerivatives 4.0 International - CC BY-NC-ND 4.0 https://creativecommons.org/licenses/by-nc-nd/4.0/ 


\title{
Rethinking risk and disasters in mountain areas
}

\author{
Kenneth Hewitt and Manjari Mehta
}

Unsafe conditions in mountains are commonly attributed to inaccessibility, isolation, "backwardness" and "fragility" stemming from rugged terrain and harsh climates; in turn, disasters are linked to greater proneness to geophysical extremes, and sparse populations or scattered resources. These "mountain specificities" have often been seen as coupled with and responsible for underdevelopment, insecurity and, as the title of this collection suggests, "marginality".

2 In contrast to a preoccupation with natural hazards in much of the disasters community and with emergency responses, we propose a vision of risk and disasters rooted in social organization and histories. A social histories approach certainly invites consideration of mountains as physical as well as social entities, but also views their risks as embedded in human land uses, activities and interactions. Commonly they are subordinated to development trends in modern states, and increasingly influenced by national economies, patterns of market and cultural integration, and processes of globalisation, not least, urbanisation in and beyond the mountains.

Drawing on examples from the Central Himalayan districts of north India and the Karakoram mountains, we show how the places and conditions where the worst losses occur are often prefigured by development trends and projects, and the absence of appropriate land-use strategies. The worst hit areas involve populations for whom basic survival and other, usually human, sources of danger and vulnerability, far outweigh environmental hazards. Their predicaments have more to do with past and present relations to down-country or metropolitan actors than mountain habitats. They relate to broader problems of degrading environments, concentration of impoverished populations, groups with little visibility and no voice in public affairs, neglected public safety concerns and, too often, development that is inappropriate to contexts and needs.

4 Such conditions loom larger than "Mother Nature" in shaping whether disasters occur and, if they do, their outcomes. They also serve to challenge the view that such 
outcomes are inevitable consequences of harsh mountain environments and "unscheduled" or extreme natural events. Rather, social policies that reflect national and international priorities and agendas play the greater role. We suggest that improvements in the latter could do much more to avoid or prevent disasters than seeking to tame or even better-predict environmental forces.

We acknowledge the still considerable numbers of indigenous Himalayan people, pursuing seemingly more typical, relatively traditional lives in their villages, if much disturbed by the modern world. Even more, however, we emphasize urban perspectives, partly because urban centres are increasingly involved in mountain land disasters, partly because they are huge in the areas where we work, and partly because of their neglect in mountain discourse. Over the past half century, in the world's more populous mountain regions, including the Himalaya-Karakoram-Hindu Kush and the Andes, people in urban centres have been rapidly outnumbering rural ones. As well as changing the incidence and scope of disasters, urbanization is a large factor in the risks for rural and "alpine" hinterlands as well as downstream regions. Urban vulnerability has certainly been addressed (Pelling, 2003), but it tends to be treated separately and to foreground the very largest cities whilst overlooking the peri-urbanisation of large swathes of highland areas. To develop these perspectives, however, the prevalence of other approaches to mountain land disasters needs to be addressed.

\section{Disasters and mountain stereotypes}

Contemporary research presents a broad range of approaches to disasters, not least in looking at social vulnerability and related concerns (Blaikie et al., 1994; Steinberg, 2000; Oliver-Smith and Hoffman, 2003; Bankoff et al., 2004; UNDP 2004; Hewitt, 2007; Enarson and Chakrabarti, 2009). Even so, it is hard to counterbalance the tendency to identify disasters by and through environmental agents that trigger them, notably in mountain lands. The more typical geo-hazards view sees disasters as consequences of nature gone badly awry - a breached river due to excessive rains, a massive earthquake that reconfigures the landscape, or mountain communities' lives put on hold by landslides closing off access to the "outer" world. Explanations and constraints are located not in social histories but in Nature's extremes, inhospitable terrain, and harsh climates (McCall et al., 1992; Rose et al., 2004). In our experience, however, disasters are never "just", or even primarily, about natural events. We find the priority given to economic growth, for example, has reconfigured mountain "riskscapes" through hydropower schemes, forestry and minerals exploitation, roads and tourism. These contribute to the changing shape and intensification of disasters more immediately and, to date, more drastically, than climate change. Disasters, insofar as they are embedded in human choices and actions that may long precede the destructive event, are preeminently social events shaped by broader structural and public safety concerns (Bradshaw, 2004).

7 Another mountain stereotype comes from romanticising the highlands as places of wilderness, as 'the last frontiers' where unspoiled, natural habitats, even "empty" areas, exist. If humans appear in this view it is in exotic communities, supposedly "untouched" by the modern world. If dangers are admitted they stem from altitude and remoteness, the "alpine" and "steepland" areas and extremes of weather, or "risk taking" mountaineers. If there is some "realism" about all this, it lies in the old 
Darwinian picture of survival in the face of an unrelenting struggle in and with Nature. It is not that there is no basis in fact, but it ignores the actual condition of the vast majority of mountain dwellers and projects, or the kinds of risks and disaster losses they endure. Above all, it turns away from the realities of development, national security and the countless mountain towns and cities which are home to more and more mountain dwellers.

Urbanisation is happening in mountain areas as fast, or faster, than many lowland regions. Unprecedented growth of dense and vulnerable settlements, or districts within cities, is occurring from Andean South America and the East African Highlands, to Central Asia and the mountainous islands of South East Asia (Fernandez, 1996; Development Planning Unit - University College London, 2003) Commonly, migrant labour from mountainous hinterlands is involved, but also populations forcibly displaced by conflict, megaprojects, disasters or quite simply pursuing jobs. These are often unusually vulnerable populations, less able to cope, and with no say in developments affecting their safety. For them, environmental hazards are usually subordinate to other basic survival needs and to human sources of risk and vulnerability. The most concentrated human risks and the greatest losses in recent disasters involve the ever-larger areas of dense inner city "slums" and emerging periurban settlements between the city and rural "wilds" (Qin Ye, 2005; Davis, 2006; UNHabitat, 2007). Moreover, to an ever-greater extent risks and disaster responses in more sparsely populated mountainous hinterlands are shaped by and from these urban centres.

9 One consequence of the tendency to emphasise remoteness and inaccessibility is to see mountain communities in terms of being isolated and autonomous in relation to their environment, and to down play or ignore their relations to surrounding areas. Almost nowhere is this the case. Rather, highland-lowland relations prefigure, often fatally, disaster risks in mountain lands. Trade, migrations, security and military adventures have historically linked the mountains to more or less distant and lowland centres. Not least important are the socio-economic and political influences, especially in this moment of economic liberalisation and globalisation. The devastating 2010 floods in Pakistan illustrated this all too well.

10 A third stereotype perceives mountains as "refuges", places of tranquility, spiritual pilgrimage and renewal, or healthy recreation, "away from it all". It may well reflect deep-seated longings or the place of mountains in human thought. We are not denying the spiritual significance people find in mountains, nor belittling efforts to protect mountain heritage. The problem lies in the striking contrast to images conjured up today by, say, Afghanistan or Guatemala; Kashmir or Chiapas; Ethiopia or Yemen. All are mountainous lands and have their alpine wildernesses, unique histories, and places of renowned beauty. However, they are uniquely associated with brutal images of armed conflict; decades of appalling guerrilla, civil or international wars (Hewitt, 1997; Libiszewski and Baechler, 1997). Even this is a selective vision, reflecting how armed violence and security questions preoccupy dominant powers and the mass media. Many, and possibly more, people in the mountains suffer from other severe problems. It may be child malnutrition, environmental degradation or refugee crises; problems that can impinge more immediately and seriously on all aspects of survival and disaster readiness. And, if aggravated or given particular twists by mountain environments, 
these problems are not actually about them but are shared with many other habitats with aggravated societal risks (Ives, 1997).

11 A final stereotype sees mountain populations as largely rural, indigenous peoples, communities pursuing "traditional", mainly agricultural and pastoral, livelihoods. This is the case in scattered areas worldwide. Much more common, however, are how their lives are integrated into modern monetary, trade, or labour markets. In the Himalaya there is work in the military, as porters and guides for visitors, as migrant labour to cities of the plains or the Persian Gulf states. People move to relatively lower Himalayan areas increasingly for schooling and white collar jobs. Migration coupled with socio-economic differentiation is re-configuring people's vulnerability to environmental as well as other hazards.

Historically, mountain communities have developed a certain resilience and coping strategies drawing on a keen knowledge of their habitats. Anthropological studies show them adapting to the diversity of these environments and finding security, even greater safety, in contexts others may find extreme and precarious (Rhoades and Thompson, 1975; Guillet, 1983; Fisher, 1986) However, as socio-economic contexts change, especially those driven by outside forces, so too have communities' abilities to grapple with conditions. Although research in this field is limited, indications are that knowledge and practices that once contributed to reducing vulnerabilities are eroding in the face of cash incentives and needs, and livelihood diversification.

\section{Debunking the stereotypes: views from Northern India}

Places and communities across the Hindu Kush-Himalaya, as in other mountain regions across the world, illustrate the extent to which mountain stereotypes fail to adequately grasp the rapidly changing contexts against which vulnerabilities and disasters are situated and why, consequently, a more nuanced approach than has hitherto been used needs to be adopted. This conceptual disconnect between perceptions, on the one hand, and increasingly complex realities, on the other hand, can be illustrated in the cases of Himachal Pradesh and Uttarakhand, located in the central Himalayan region of north India. Both states are characterised by some highly built-up areas and urbanising environments, populations that are increasingly differentiated socio-economically, and following development trajectories which closely mirror or are influenced by downstream decisions and actions.

This region's engagement with other mountain and lowland political economies extends back prior to the colonial period, and has greatly intensified in the decades following independence. Since the 1960s, with geo-political imperatives to make the higher reaches of these mountains accessible, the construction of all-weather and rural roads has been a top development priority. They provide modern life-lines to formerly relatively isolated communities, create more and faster links to markets, employment, education and other opportunities. Today, the degree of inaccessibility that still applies in some parts of the Nepal Himalaya is non- existent here. Few areas are untouched by roads offering relatively easy access to the marketing centres and peri-urban conglomerations which have sprung up along them. Major hill stations like Shimla and Mussoorie, as well as once-small villages like Kullu and Manali, have experienced tremendous expansions of population and unregulated growth, much of it occurring in areas vulnerable to seismic activity. An additional feature of urban and satellite 
township growth is the heavy pressure placed on water and electricity supplies, and sewage systems and other civic amenities that are grossly inadequate in meeting demands.

These trends have intensified in the past two decades coinciding with the liberalising of the Indian economy. The unprecedented economic and social growth engendered in much of the country, has also left its mark in the mountains. It is epitomised by "revolutions" in the transportation and communication sectors, the emergence of a large middle class with new aspirations and purchasing ability, and a vibrant consumer culture. Access to greater disposable income coupled with easier mobility and the acquisition of dominant socio-cultural mores are helping to bring about huge changes. Some people are taking advantage of new opportunities in work and education. Some areas are seeing diversification of farm and off-farm incomes. Inevitably such changes have also brought dilemmas, and it is instructive to see how these are shaping risky situations that had been absent before or did not encompass such large areas and numbers of people.

A major consequence of the formation of Uttarakhand out of the hill districts of Uttar Pradesh in 2000 has been the upward spiral of land prices and the emergence of property speculation. What began around the designated state capital, with conversion of once-agricultural lands into non-farm entrepreneurial or residential concerns, has subsequently moved further "up hill" fuelled by a long-standing scenario of low and stagnant agricultural returns, the growing need for income, and access to new sources of disposable income. The demands of a shifting population, both from within these mountains and from the plains, and ranging from labourers to the middle class, has also helped to feed this shift in land use and a building boom. An emerging "hospitality" sector, catering to a domestic urban middle class with the desire to travel, acquire and consume, has also contributed to the changing configuration of both land and population. There has been a considerable expansion of already over-crowded urban areas. Once sleepy towns have been transformed into sprawling urban settlements typified by high population densities and bearing little resemblance to conditions of even a decade ago. The type of infrastructure required to support this increasingly middle class, urban population has also placed heavy pressure on water, electricity, sewage systems and roads, depleting an increasingly scarce water base and creating a growing crisis of solid waste management. Glimpses of this newly built environment are everywhere: modest housing sits next to residential complexes, glassfronted hotels dot ridges, road-side eateries abut ubiquitous shopping arcades, lodges and food stalls. Garbage, that most visible evidence of India's new throw-away consumerism, is strewn everywhere.

17 Ironically, this newly-formed mountain state's development is now proceeding largely in the absence of a coherent land use policy, or of environmental guidelines and regulatory oversights sensitive to mountain needs and contexts. The outcome is rising levels of air pollution, and serious traffic congestion on ill-equipped roads. Multistoreyed buildings are being constructed without attention to appropriate building codes in areas known to be seismically sensitive. Meanwhile, marginalised populations, whether urban or rural, continue to do what they have always done: build on the only lands available to them on vulnerable slopes. Shanty towns with inadequate housing and absent infrastructure occupy the cheapest sites at risk from a variety of natural hazards. Lack of provisions for disposing of construction debris has resulted in the 
clogging of natural drainage systems, leading to floods during the rainy season. Roads sink and collapse, electricity lines trail in open drains.

A related, if rarely commented on, phenomenon is how the populations in these urban and peri-urban centres are becoming more diversified, with migrants from rural areas as well as from the plains. There are students, civil servants, military personnel and middle class second home owners: people who can claim to be of, if not always from, the mountains. They constitute an ever-expanding population at risk from living in urban contexts in which civic authorities offer few supports and protections and where quality of life issues loom large, if rarely addressed. Virtually all densely populated urban areas and townships are settings where "everyday disasters", from high infant mortality to crime, occur. Supposedly "accidental" deaths take their toll, ranging from motor vehicle collisions to electrocution. The implications in such a diverse population, for awareness of, and investment in, increased public safety and resilience and reducing vulnerabilities, remain to be examined.

The 2010 monsoons showed how geological and climatically induced hazards, whether increasing in frequency and intensity or not, are exacerbated in inadequately built and regulated environments, and aggravated by artificially induced disorder in urban-rural and upstream-downstream linkages. Potentially high growth sectors, such as hydropower, tourism and roads/infrastructure, not only have the highest environmental fallouts but also affect large numbers of mountain people and put many hundreds of thousands in the plains at risk.

The unprecedented flash floods that devastated much of Pakistan in 2010 also caused havoc across Himachal Pradesh, Uttarakhand and other areas in the mountains and across the Gangetic plains. Floods, cloudbursts, and landslides disrupted lives and livelihoods in the mountains as well as those of many millions living in the flood plains of northern India. Entire villages and towns were inundated, with rivers in spate and embankments breached, roads washed away and blocked or severely damaged by landslides breaking off critical lifelines for more isolated rural communities. The threat from rising water levels in Tehri Dam and inundations downstream along the Ganges emphasised the serious impacts of upstream-downstream linkages. Villagers and urban dwellers alike suffered huge losses, whether in agriculture, animal husbandry and entrepreneurial activities; urban and peri-urban infrastructure was badly affected and in some instances even destroyed, and the flow of essential commodities, now largely transported from the plains, was severely disrupted. One of the key religious pilgrimage seasons was also badly affected, with many thousands of mostly urban visitors from the plains being caught in landslides, often for days.

21 Terrible though they were, these events exemplify what is played out, to a greater or lesser degree, in most years throughout this region. Only, this time, its scope was more severe because of the many different kinds of people, places and infrastructure affected, and cast a light on how ill-equipped local authorities were to respond. There was poor coordination amongst various agencies ostensibly dealing with emergency rescue operations, and a general lack of awareness within increasingly heterogeneous communities about what they could or should do in such situations. 


\section{Karakoram villages: faces of vulnerability}

Many of the same developments are found in the northern mountains of Pakistan, especially with the rapid growth of towns in valleys between the Himalayan foothills and high mountains of the Northwest and Karakoram Himalayas. The consequences are evident in the recent history of centres like Muzzaffarabad, Abbotabad, Mingora and Dir. The critical roles of modern infrastructure, and more densely urbanised areas, suddenly become visible in major disasters. They include the rains and floods of September 1992, and August 2010, originating in the mountains, causing great damage there, but identified far more with death and destruction downstream in the plains. The town populations and mushrooming "villages" along highways, were again the worst-hit in the 2005 earthquake; in the Atabad, Hunza landslide of January 2010 and, equally, in the Swat insurgency of 2009.

In the Karakoram and Hindu Kush valleys of the Upper Indus basin, towns have been growing fast, notably since completion of the Karakoram Highway (KKH) in the 1970s. This links the lowlands of Pakistan with China, and has stimulated a spate of road building to almost every community in the high mountains. Nevertheless, most people still reside in villages where much of - though by no means all - material life involves more or less traditional forms of agriculture and pastoralism. Even in major regional disasters, these communities rarely obtain much or any assistance from the state, and not at all for most local disasters. Risk and response play out mainly within the village context. As such, it has seemed, the more "typical" Himalayan predicaments arise; damaging events described and ascribed primarily to natural hazards and rugged terrain (Kreutzmann, 1994; Hewitt, 1997; Stellrecht, 1998).

24 Space permits just one example here, but one that still challenges the stereotypical views of the mountain environments and their hazards described earlier. It helps to move from the broad brush sense of changing risk conditions under modernisation given above, to the specifics of how they involve individuals, families, and communities. The focus on village women in relation to natural hazards again reveals how social histories rather than the mountain habitat per se govern risks.

\section{Hidden Hazards, Invisible Distress - The relevancy of a gender approach}

5 In the 1980s a team of Canadian researchers were monitoring a glacier in the Karakoram, the Bualtar (or "Hopar") Glacier in Nagyr. While there, elders from the Hopar villages asked us to investigate the loss of village lands where they overlook the glacier. At one level the problems were clearly due to natural hazards: large landslips breaking away and sliding down the cliff to the glacier. According to weather and season there were also countless smaller stone and earth falls. Far down the cliff, below the villages, were sections of broken road, stone terraces, and irrigation channels, carried away by the landslides.

Since the last major glaciation, a great build up of deposits around the lower Bualtar and Barpu Glaciers created sites relatively attractive for settlement and cultivation. However, for some centuries, the glacier had been cutting down to expose near-vertical walls in its old lateral deposits. The impacts have been accelerated by glacier surges, 
when the ice suddenly thickens, travels much faster for some months, and releases floods of melt water (Hewitt, 2009). The main problems were along a series of cliffedges more than $20 \mathrm{~km}$ in length where some $3-4 \mathrm{~km}^{2}$ of land had been removed in the previous three decades. Land loss, damage to irrigation systems and the road into the villages, and difficulties of access to important resources across the glacier, are the main, direct impacts. However, while the scale is huge for the villages, the process is slow - what some call a "creeping hazard" (Smith, 1992) - and there were no direct casualties or loss of life.

We could model and monitor the landslides, measure the losses, but there is no prospect of stopping them. This was no surprise to the village leaders. Their problem was to get official recognition of the scale and scope of the impact on their lives; never easy with a "creeping disaster". They merely hoped a report by us could be used to get government or NGO assistance.

More surprisingly, we also discovered that there is land that could be reclaimed to replace that being lost. In fact, away from the villages even more land has been abandoned in recent years than lost to the landslides. And this applied even though the numbers of children and rate of population growth in these villages are notoriously high. So we suggested they forget the landslides and open up new land.

In fact, the villagers had made a major effort in land reclamation after a 1970s flood disaster. Interestingly, in that case land loss was negligible, but it killed 25 persons and such a tragedy led to substantial compensation, and outside assistance. The villagers stressed how they were given wheelbarrows, explosives, irrigation pipes, cement, and funds to pay men folk a wage to do the work.

While the male researchers were surveying glaciers and landslides Dr. Azhar-Hewitt (2011) had got to know the women of Hopar. She discovered the real harm being done by the landslides - and why it was hard to do anything about it! In essence it involved the clash of the traditional and modern stresses on village life, in this instance related to the gendered-division of labour and the desires/need for cash. It was doubly hidden as secondary or tertiary hazards of landslides, where most outsiders had no access and very little awareness. Certainly spring, summer and fall, women were seen at work in the fields, on rooftops, or milking an animal, and always surrounded by small children. Every day young girls would be sprinting across the glacier in plastic flip-flops to collect kindling or care for small animals at Shishkin settlement across the ice, otherwise abandoned because of the landslides.

The main requests coming from the village women were for medicines, advice about their own health, and children's' ailments. Most were under constant stress, surprisingly strong but very thin. They had recurring problems with palpitations, menstrual bleeding, and other signs of over-work and distress. And there were almost no older women. Most died before their fortieth year, often in childbirth. Such tribulations exist everywhere in marginalized communities, so what have they have to do to landslide hazards?

32 Firstly, the loss of land was mainly where women work, and affecting facilities on which they are most dependent. The worst damages occurred close to the villages; the spaces where women spend most of their lives. Secondly, their primary role is to produce food for family and village. Land loss made it ever-harder to maintain the level 
of production, even as the number of mouths to feed was growing. They had to work longer hours and further afield, requiring more walking and carrying.

The men folk knew about this. They may or may not have seen this was killing their women but, as we discovered, few can or will give up jobs for cash, mainly outside the villages. The economy of each household, their hopes for their children, their expectations, told the story. They need shoes and schoolbooks for children, tools, seeds, disinfectant or pesticides, and antibiotics when someone is sick. Clothing must be bought because cheap imports replaced their own home-made cloth and shoes a generation ago. Electricity had come and must be paid for, along with light bulbs and appliances. Weddings go on, and it is no small matter to save up to send men on Haj, pilgrimage to Iran or Mecca. Compelling too are the desire to buy a watch, a radio, a better stove, glass for windows, and clothes for special occasions. Nothing like this comes without cash. Households with too few or no men bringing in cash suffered some of the worst problems; such are pressures from the outside world, and not unfamiliar ones. Many men spend their working life in gruelling jobs down country, on the roads, in the army, carrying heavy loads for mountaineering groups. Neither they nor their women are ready to give up rewards that only money can buy, to spend the time opening up and servicing new crop land.

In sum, the main impacts of the landslides emerged within the traditional village economy as a tertiary hazard, constrained by the gender-division of labour and modernization. As such it was borne primarily by village women, struggling to make up for loss of land and other resources, and to complement men's wage work. And it creates serious questions about what to do. Only assistance in the form of money and tools will induce the men to reclaim land, the obvious solution. However, the traditional economy is under great pressure anyway. NGO and other outside assistance is more often available to change it, say by providing tractors that only men can drive, or investing in commercial crops like seed potatoes, or more animals to sell for meat in the towns or to tourist hotels. Subsistence production helps families through the ups and downs of the modern wage economy but, increasingly, families reach a point where they head off to the towns, taking their women into more familiar "housewife" roles or even paid work. Subsequently, a hospital and clinic were built in Hopar and evidently addressed some of the problems identified above but, again, the clash of "traditional" and modern frustrates the initiative. For example, there are no women doctors and nurses from the community and no outside professionals are able to fit in with the village life style. It is an object lesson in the preconditions of vulnerability that appear in disasters.

\section{Concluding remarks}

Changes in the mountains, as we saw in the burgeoning cities, can be highly visible in the landscape; danger is evident in the terrible damages in earthquake and flood. It is much harder to read the webs of social exchange and expectations, heritage and values, least of all abilities and vulnerabilities in mountain communities. Scientists commonly miss these conditions, fail to appreciate how modernisation projects may be implicated in them or run rough-shod over them. Nevertheless they speak to the fabric of life in which people are at risk and able, or unable, to respond. Even the most stereotypical of 
mountain risks, the Hopar landslides, provided an unexpected window on the greater and more complex hazards of social change in the mountains.

Exposure to external markets, geostrategic "games", and their associated stresses, are by no means new to mountain communities in High Asia or elsewhere. What is new is the scope and rapidity of changes, many of which, located in processes of economic globalisation and global environmental change, give communities little or no control over them. Faltering subsistence economies, migrant labour or forced displacements and rapid urbanisation, heighten the risks from natural hazards by concentrating and increasing the vulnerability of certain segments of populations. They are most likely to live in more dangerous, least well-protected places, and with little or no influence over public safety measures.

Here are the major, new forms of marginalisation, rather than a passive consequence of difficult and remote environments, let alone lack of knowledge. Increasingly, risks are outcomes of planned developments in which the condition of mountain habitats and concerns of their inhabitants are ignored. In this scenario, disasters appear less as "unscheduled events" than as "collateral damage", inevitable unplanned outcomes of prevailing strategies that make little or no effort to prevent them. Without an action agenda that speaks to the specific vulnerabilities of mountain eco-systems and communities, it seems unlikely that improvements will occur (IFRCRCS, 2004). Equally, however, they cannot be treated in isolation from the wider social, economic and political systems.

Experienced students of mountain lands, especially those looking at social and ethnographical matters, have long challenged the old stereotypes (Oliver-Smith, 1986; Maskrey, 1989). Our examples serve to highlight the ways in which dangers, no less than development trajectories, reflect social histories. This is not to say mountain habitats and environmental hazards are unimportant, or that their specific challenges can be ignored. They are always of key concern for people inhabiting the places where they arise. Nevertheless, the main question is reading them in relation to the lives and conditions of those most likely to suffer in disasters.

These observations foreground the need for a more nuanced understanding of how disaster situations and outcomes arise and can be addressed. The promise of Hyogo was to highlight the need to bring sustainable development to the forefront of disaster risk reduction approaches (UNISDR, 2005; United Nations 2004). A key element of Hyogo was to develop capacities and forge linkages across "social capital" sectors. However, mountain communities are being rendered increasingly vulnerable on a host of fronts and when the costs of disasters in terms of lives, livelihoods and infrastructure are increasing. One has to ask how successful has been the application of Hyogo principles in bringing a more socially-inclusive approach to the mountain context. In this regard, while disaster management is increasingly institutionalized in security agencies, it remains to be seen how effectively they are developing working relationships with local civic, community and other relevant local-level bodies. This takes on greater urgency at a time when mountain areas are suffering more disasters and their attendant social and economic costs are increasing. It invites consideration of the types of inputs that a more diverse and engaged mountain-based population could inject into risk-reduction activities. 


\section{BIBLIOGRAPHY}

AZHAR-HEWITT F., 2011. - The other side of silence : lives of women in the Karakoram Mountains, Universe, Bloomington.

BANKOFF G., FRERKS G., and HILHORST D., 2004. - Mapping vulnerability : disasters, development and people, Earthscan, Londres.

BLAIKIE P., CANNON T., DAVIS I., WISNER B., 1994. - At risk : natural hazards, people's vulnerability and disasters, Routledge, Londres.

BRADSHAW S., 2004. - Socio-economic Impacts of natural disasters : a gender analysis, Manuales 32, United Nations Economic Commission for Latin America and the Caribbean, Santiago.

DAVIs M., 2006. - Planet of slums, Verso, New York.

DEVELOPMENT PLANNING UNIT - University College London, 2003. - Understanding slums : case Studies for the UN-Habitat global report 2003, Development Planning Unit. University College London , Londres.

ENARSON E., DhAR CHAKRABARTI P.G., 2009. - Women, gender and disaster : global issues and initiatives, SAGE, New Delhi.

FERNANDEZ M.A., 1999. - Cities at risk : environmental degradation, urban risks and disaster in Latin America, LA RED - The Network for Social Studies on Disaster, Lima.

FISHER, J.F., 1986. - Trans-Himalayan traders : economy, society and culture in Northwest Nepal, Motilal Banarsidass, New Delhi.

GUILLET D., 1983. - « Towards a cultural ecology of mountains : the central Andes and Himalayas compared ». Current Anthropology, Vol. 24, n5, pp 561-74.

HEWITT K., 2009. - « Rock avalanches that travel onto glaciers : disturbance regime landscapes, Karakoram Himalaya, Inner Asia ». Geomorphology, Vol. 103, pp 66-79.

HEwITT K., 2007. - « Preventable disasters : addressing social vulnerability, Institutional risk and civil ethics ». Geographische Rundschau - International Edition, Vol. 3, n²1, pp 43-52.

HEWITT K., 1997. - Regions of risk : hazards, vulnerability and disasters. Longman, London.

IVES J.D., 1997. - «Comparative inequalities : mountain communities and mountain families ». In B. Messerli et J. D. Ives (eds.) Mountains of the world : a global priority. The Parthenon Pub. Corp., New York, pp 61-84.

IFRCRCS, 2004. - World disasters report : focus on community resilience. International Federation of Red Cross and Red Crescent Societies, Genève.

KREUTZMANN H., 1994. - « Habitat conditions and settlement processes in the HindukushKarakorum ». Petermanns Geographische Mitteilungen, Vol. 138, n6, pp 337-356.

LIBISZEWSKI S., BAECHLER G., 1997. - « Conflicts in mountain areas : a predicament for sustainable development ». In B. Messerli et J. D. Ives (eds.) Mountains of the world : a global priority. Parthenon, New York, pp 103-130.

OLIVER-SMITH A.S., 1986. - The martyred city : death and rebirth in the Andes, Waveland Press, Prospect Park. 
OliveR-Smith A.S., AND HoffmAn S.M., 2003. - The angry earth, Routledge, New York.

MASKREY A., 1989. - Disaster mitigation : a community based approach, Oxfam, Oxford.

McCALL G.J.H., LAMING D.J.C., ScotT S.C.,1992. - Geohazards : natural and man-made, Chapman Hall, Londres.

PELLING M., 2003. - The vulnerability of cities : natural disasters and social resilience, Earthscan, Londres.

QIN Y., 2005. - « Living in between : periurban and wildland interface habitats ». In T. Jeggle (ed.)

Know risk. Tudor Rose Publications / United Nations International Strategy for Disaster

Reduction, Leicester / Genève, pp 318-321.

RHOADES R.E., THOMPSON S.I.,1975. - « Adaptive strategies in alpine environment beyond ecological particularism ». American Ethnologist, Vol. 2, n³, pp 535-551.

ROSE W.I., BOMMER J.J., LOPEZ D.L., CARR M.J., MAJOR, J.J., 2004. - Natural hazards in El Salvador, Special paper $n^{\circ} 375$, Geological Society of America, Boulder.

SмIтн K., 1992. - Environmental hazards, Routledge, Londres.

STEINBERG T., 2000. - Acts of god : the unnatural history of natural disaster in America, Oxford University Press, New York.

STELLRECHT I., 1998. - Karakorum-Hindu Kush-Himalaya : dynamics of change, Rüdgers Köppe Verlag, Cologne.

UNDP, 2004. - Reducing disaster risk : a challenge for development, United Nations Development Programme - Bureau of Crisis Prevention and Management, New York.

UN-Habitat, 2007. - Global report on human settlements 2007, Earthscan, Londres.

UNISDR, 2005. - Building the resilience of nations and communities to disaster : an introduction to the Hyogo Framework for Action, United Nations International Strategy for Disaster Reduction, Genève.

\section{ABSTRACTS}

This chapter presents a view of risk and disaster in the mountains that finds them fully a part of public safety issues in modern states and developments, rather than separated from them. This contrasts with prevailing approaches to disaster focused on natural hazards, "unscheduled" or extreme events, and emergency preparedness; approaches strongly reinforced by mountain stereotypes. Rather, we find the legacies of social and economic histories, especially relations to down-country or metropolitan actors, are decisive in shaping contemporary "mountain realities". Developments in transportation, resource extraction and tourism that serve state and international agendas can increase rather than reduce risks for mountain populations, and undermine pre-existing strategies to minimise environmental dangers. Above all, we see rapid urbanisation in mountains generally and the Himalaya in particular as highly implicated in exacerbating risks and creating new types of vulnerabilities. Enforced displacement, and concentration of people in urban agglomerations, is a major part of the modern history of mountain lands that invites more careful exploration. Rapid expansion of built environments and infrastructure, without due regard to hazards and structural safety, introduce new and complex risks, while altering older equations with and to the land and sapping people's resilience. In the lives of mountain people, environmental hazards are mostly subordinate to other, societal 
sources of risk and vulnerability, and to the insecurities these involve. Basically we conclude that "marginalisation" of mountain lands is primarily an outcome of socio-economic developments in which their condition is subordinated to strategic planning by state, metropolitan and global actors.

Cet article aborde la question des risques et des catastrophes en montagne. Il vise non pas à dissocier mais plutôt à replacer ces concepts au cœur des questions de sécurité publique et de développement des États contemporains. Cette approche des catastrophes se distingue des précédentes, pourtant considérablement renforcées par les stéréotypes habituels, propres à l'environnement montagnard. De fait, celles-ci étaient jusqu'alors centrées sur l'aléa naturel, sur son caractère extrême et imprévisible, ainsi que sur la réponse post-catastrophe (phase d'urgence). La prise en compte d'autres facteurs apparaît nécessaire. Les héritages des histoires économique et sociale des territoires montagnards, et, plus particulièrement, les relations tissées avec les acteurs métropolitains et le reste du pays, contribuent, de manière décisive, à façonner la réalité contemporaine des montagnes. Le développement des transports, l'extraction de ressources et le tourisme, qui profitent à l'État et s'inscrivent dans la tendance internationale, peuvent paradoxalement accroître le risque pour les populations montagnardes et saper les stratégies préexistantes destinées à réduire le risque environnemental. Plus que tout, l'urbanisation rapide des montagnes en général, et de l'Himalaya en particulier, a largement contribué à intensifier les risques et à créer de nouvelles formes de vulnérabilités. La majeure partie de l'histoire actuelle des montagnes reste influencée par les déplacements contraints de population et la densification des centres urbains. Cela doit faire l'objet d'une analyse particulière. L'expansion rapide du bâti et des infrastructures, mis à part la sécurité de ces structures, engendre des risques nouveaux et complexes et détériore parallèlement le rapport habituel des hommes à leurs terres, en dégradant ainsi la capacité de résilience des individus. Dans la vie quotidienne des peuples montagnards, les catastrophes environnementales sont bien souvent dépendantes d'autres formes sociales de risque, de vulnérabilité et d'une insécurité corollaire. Pour conclure, la marginalisation des espaces montagnards reste avant tout la conséquence du développement socio-économique de ces territoires, dont les paramètres dépendent des stratégies de développement de l'État et des acteurs métropolitains et internationaux.

\section{AUTHORS}

\section{KENNETH HEWITT}

Department of Geography and Environmental Studies, Wilfrid Laurier University, Canada, khewitt@wlu.ca

\section{MANJARI MEHTA}

Social Anthropologist and independent researcher, Dehra Dun, India,manjari.mehta@gmail.com 